\title{
The Relationship Among Helicobacter pylori Positivity, Acute Phase Reactants, Blood Groups and Tumor Markers in Urea Breathe Test
}

\author{
Ali Şenkaynağ ${ }^{1}$, Mustafa Yıldız ${ }^{1}$ \\ ${ }^{1}$ Department of Nuclear Medicine, Faculty of Medicine, Süleyman Demirel University, Isparta, TURKEY \\ Received: 19 April 2017 Accepted: 25 July 2017, Published online: 28 August 2017 \\ (C) Ordu University Institute of Health Sciences, Turkey, 2017
}

\begin{abstract}
Objective: In this study, positivity of Helicobacter pylori which is very common health problem for human, was examined by $\mathrm{C} 14$ urine breath test and in this group also blood samples, acute phase reactants, tumor markers were examined for the specific correlation

Methods: Blood samples of 130 patients which was examined by $\mathrm{C} 14$ urine breath test, were drawn. In order to perform the urea breath test, which was the basis of our study, the patient was starved for at least 6 hours before the test and did not use antibiotics 1 month before and active acid inhibitors 1 week before. Following a 6-hour hunger period, $37 \mathrm{kBg}$ of $14 \mathrm{C}$-urea capsules $50 \mathrm{~mL}$ water were given. Breath samples were collected at 10 minutes with a dry cartridge system (BREATHCARD). In this group also blood samples, acute phase reactants (crp, aso, sedim, rf), tumor markers (CEA, CA 19-9, CA 15-3) were examined for the specific correlation.

Results: Test results for 57 of 130 patients were found to be positive $(43.84 \%)$ while it was found to be negative (56.16\%) in 73 patients. Reference ranges for blood parameters were 13.6-17.2 for HGB, 39.5-50.3 for HCT, 5.2-12.4 for WBC, 0-200 for ASO, 3.02 for CRP, 0-15 for RF, 0-3 for CEA, 0-35 for CA 19-9, 031.3 for CA 15-3 The mean age of patients with negative $\mathrm{H}$. pylori infection was 39.41 and the positive was 39.03. 35 of the $57 \mathrm{H}$. pylori positive patients in the total 130 patients were female $(61.4 \%), 22$ were male (38.6\%); Of 73 negative patients, 44 were female (60.3\%) and 29 were male (39.7\%). There was no sexrelated collagen of $H$. pylori. 22 persons (38.6\%) of the positive H. pylori blood group were found in the blood group A, $9(15.8 \%)$ were in the blood group B, 11 (19.3\%) were in the group AB and $15(26.3 \%)$ were in the group O. It was observed that 21 patients (28.8\%) in negatives of $H$. pylori were blood group A, 17 patients (23.3\%) were blood group B, 14 patients (19.2\%) were blood group AB and 21 patients (28.8\%) were group $\mathrm{O}$. No significant difference was observed between blood groups and $H$. pylori infection with $\mathrm{Rh}$ factor, and no linkage was detected.

Conclusion: As a result, there were no significant correlation were found between acute phase reactants, tumor markers and $\mathrm{ABO} / \mathrm{Rh}$ blood groups for $H$. pylori positives.

Key words: H. pylori, C-14 urea breath test, tumor markers, acute phase reactants, blood groups,

Address for correspondence/reprints:

Ali Şenkaynağı

Telephone number: +90 5065354600

E-mail: alisenkaynagi@sdu.edu.tr

DOI: $10.19127 / \mathrm{mbsjohs.307150}$

\section{Introduction}

Helicobacter pylori is a rod-like, spiral, gram negative, microaerophilic microorganism. It is known as a responsible of chronic active gastritis, peptic ulcer disease, stomach cancer and etiology of stomach lymphoma "mucosa-associated lymphoid tissue" (MALT). H. pylori is also implicated in the etiopathogenesis of certain non-gastrointestinal disease such as atherosclerosis, diabetes mellitus,
\end{abstract}


and insulin resistance (Aslan, 2006). Intrafamilial transmission is especially important during childhood. The major transmission route is considered to be fecal-oral as well as oral-oral and gastro-oral routes (Cammarota et al., 1998; Ma et al., 1998). The infection of $H$. pylori is the most common chronic infectious disease. It is predicted that approximately half of the world population has H. pylori infection, prevalence is estimated to be 70$90 \%$ in developing countries and $25-50 \%$ in developed countries as well. Infection is mainly acquired by oral way of bacterium and there is intrafamiliar transmission (Dunn et al., 1997).

In order to identify the $H$. pylori, is infected at an early age, a number of invasive method for requires esophagus gastroduodenoscopy and non-invasive methods for not requires esophagus gastroduodenoscopy have been developed. There is no specific signs and symptom for $H$. pylori diagnosis. Therefore, availability of $H$. pylori is only possible in laboratories. There are only two tests in diagnoses which are non-invasive (Urea Breath Test, Serological Methods, Stool Antigen Tests, Stool Polymerase Chain Reaction-PCR and Fecal Antigen Test) and invasive (Culture, Histopathology and Urease Test, Molecular Diagnostic Methods) methods (Logan et al., 1991; Gürakan et al.,1996; Gramley et al.,1999; Cavallini et al.,2000; Manes et al.,2004; Y1lmaz YA,2004; Schabereiter et al.,2004; Usta and Özen,2007). None of these tests are alone $100 \%$ sensitive and specific for diagnosing $H$. pylori, and it is suggested to combine two test for diagnosis if possible (Usta and Özen,2007). In recent years, most of the studies oriented towards the eradication of $H$. pylori have been made with proton pump inhibitor $(\mathrm{PPi})+$ antibiotic combinations. Triple therapies consisting of clarithromycin and amoxicillin or metronidazole in combination with a PPi are highly effective and widely used in $H$. pylori eradication (Laine et al.,2000). Today, radiographic methods have no role in $H$. pylori infection or gastritis and ulcer diagnosis. However, they are used as adjuncts in cases complication is to develop (Drumm et al.,1988).

When the human body is exposed to any disease, many different conditions such as inflammation, infections, neoplasms, trauma and various stress factors, $\mathrm{C}$ reactive protein (CRP), serum amyloid-A protein (SAA), fibrinogen, ferritin, $\alpha-1$ antimymotripsin, $\square-1$ antitrypsin, $\square-1$ acid glycoprotein, haptoglobulin, seruloplazmin, complement $\mathrm{C} 3$ and $\mathrm{C} 4$ proteins which are acute phase reactants or 1 interleukin-1 (IL-1), IL-6, and tumor necrosis factor- $\alpha$, which are known as proinflammatory cytokines, acute phase reactants or acute phase proteins with antitrypsin, $\alpha-1$ acid glucoprotein, haptoglobulin, ceruloplasmin, (TNF$\alpha$ ), approximately 30 proteins are synthesized in the liver, and these proteins aren't specific to any disease, but usually increase in parallel to severity of the disease (Biolo et al.,1997; Volanakis 2001).

A part from CRP proteins, tumor markers are used to detect specific malignancies specific serum antigens. These tumor markers (tm) are valuable in assessing response for treatment and determining early relapses. Carcinoembryonic antigen (CEA) can help the determining CA 19-9 colorectal cancer relapse and identifying the nature of pancreatic masses. CA 125 may be useful in evaluating pelvic masses in postmenopausal women, following treatment response in over cancer and determining their recurrence. Alfa-fetoprotein (AFP) is a hepatocellular carcinoma marker, sometimes used for screening in selected populations and may be used to monitor malignant changes in hepatic masses. $\beta$-hCG is used to diagnose and follow gestational trophoblastic disease. The combined AFP and $\beta$-hCG nonseminemematous germ cell tumors are very important in the evaluation, treatment and follow-up response. These molecules in blood are usually glycoproteins that can be identified by monoclonal antibodies. It has important role in screening, diagnosis and prognosis determination of each tumor marker, follow-up response and monitoring of cancer recurrence (Greg et al.,2003). Whether or not there is a correlation between the distributions of $H$. pylori in the blood groups has been noted by some researchers. A study reported that $H$. pylori positivity is not correlation of $\mathrm{ABO}$ and $\mathrm{Rh}$ blood group distribution (Türkölmez et al., 2007).

In this study, it was aimed to present the shortest and the most accurate diagnosis of $H$. pylori positivity which is a major problem for humanity by using blood groups and tumor markers in acute phase reactors.

\section{Methods}

This study was carried out between January and September 2008 at Süleyman Demirel University, Faculty of Medicine, Department of Nuclear Medicine. This study was performed on 130 patients with gastrointestinal complaints (dyspepsia, abdominal pain, distension, etc.) who were referred to the Department of Nuclear 
Medicine due to the suspicion of $H$. pylori infection from other clinics. H. pylori infection was investigated in all patients by $\mathrm{C}-14$ urea breath test.

In order to perform the urea breath test, which was the basis of our study, the patient was starved for at least 6 hours before the test and did not use antibiotics 1 month before and active acid inhibitors 1 week before. Following a 6-hour hunger period, 37 $\mathrm{kBg}$ of $14 \mathrm{C}$-urea capsules $50 \mathrm{~mL}$ water were given. Breath samples were collected at 10 minutes with a dry cartridge system (BREATHCARD). Patients flashed the mouth of the cartridge for 1 to 4 minutes until the indicator membrane turns from orange to yellow (Rowland et al.,1997).

The ready-to-evaluate cartridge (BREATHCARD) was run on the analyzer (HELIPROBE) for 250 seconds and the results were taken. The entire process took about 20 minutes and the results were obtained as CPM and Grade according to cartridge activities.

The results obtained as Graded were evaluated according to the following scale

Grade $0=$ No infection

Grade $1=$ Suspicious

Grade $2=$ Evaluated according to the infection scale.

In case of GRADE 1, the analyzer repeats the reading process (Özcay et al., 2004; Hino et al., 2004). Blood parameters were studied at Blood Bank of Süleyman Demirel University, Department of Biochemistry and Department of Microbiology. The parameters were determined by the Blood Group Gel Centrifugation method by using a device called as Diamed with gel card system. HGB, HCT, WBC values have been identified by photometric method in Coulter LH 750 ANALYZER brand, SEDIM is by precipitation method in LINEAR THERMA brand, ASO, CRP, RF by Nefolometric method in BN PROSPEC brand, AFP, CEA, CA 19-9, CA 15-3 by Kemilümmansans method in IMMULITE 2000 and UNICEL D $\times$ I 800 (Access Immunoassay System).

In this study, analysis was performed the difference of two group means using t-test.

\section{Results}

In this study, $H$. pylori infection frequency was controlled and test results for 57 of 130 patients were found to be positive (43.84\%) while it was found to be negative $(56.16 \%)$ in 73 patients. The mean age of patients with negative $H$. pylori infection was 39.41 and the positive was 39.03. As shown in Table 1, 35 of the $57 \mathrm{H}$. pylori positive patients in the total 130 patients were female (61.4\%), 22 were male (38.6\%). For 73 negative patients, 44 were female $(60.3 \%)$ and 29 were male $(39.7 \%)$.

22 persons (38.6\%) of the positive H. pylori blood group were found in the blood group A, 9 (15.8\%) were in the blood group B, 11 (19.3\%) were in the group $\mathrm{AB}$ and $15(26.3 \%)$ were in the group O. It was observed that 21 patients $(28.8 \%)$ in negatives of $H$. pylori were blood group A, 17 patients (23.3\%) were blood group B, 14 patients (19.2\%) were blood group $\mathrm{AB}$ and 21 patients $(28.8 \%)$ were group $\mathrm{O}$ (Table 2).

In the blood samples taken from the trial patients, the blood parameters according to the results of the blood groups and tumor markers in the acute phase reactants, the hemoglobin average in the negatives and positives were 14.63 and 14.26. Reference ranges for blood parameters were 13.6-17.2 for HGB, 39.5-50.3 for HCT, 5.2-12.4 for WBC, 0-200 for ASO, 3.02 for CRP, 0-15 for RF, 0-3 for CEA, 0-35 for CA 19-9, 0-31.3 for CA 15-3. The HCT average in the negatives was 42.14 and 41.26 in the positives. The WBC average in the negative was 6.90 and 6.96 in the positive. The average sedimentation in the negatives was 10.68 and 12.89 in the positives. The ASO average in the negatives was 157.03 and 152.46 in the positives. The CRP mean for negatives was 4.59 and 3.62 for positives. The RF average was 11.33 for negatives and 10.92 for positives. The AFP mean in negatives was 2.38 and 2.26 in positives. The CEA average for negatives was 1.59 and 2.26 for positives. The CA average 19-9 in the negatives was 10 and 8.99 in the positives. The CA average 15-3 in the negative was 15 and 14.75 in the positives (Table 3 ).

Table 1: Gender distribution of H. pylori

\begin{tabular}{ccccc}
\hline & & \multicolumn{3}{c}{ Gender } \\
& & Female & Male & Total \\
\hline hp & Negative & 44 & 29 & 73 \\
& & $60.3 \%$ & $39.7 \%$ & $100 \%$ \\
& Positive & 35 & 22 & 57 \\
& & $61.4 \%$ & $38.6 \%$ & $100 \%$ \\
Total & & 79 & 51 & 130 \\
& & $60.8 \%$ & $39.2 \%$ & $100 \%$ \\
\hline
\end{tabular}


Table 2: Distribution of $H$. pylori to blood groups

\begin{tabular}{|c|c|c|c|c|c|c|}
\hline \multicolumn{7}{|c|}{ Blood group } \\
\hline & & A & B & $\mathrm{AB}$ & 0 & Total \\
\hline \multirow[t]{4}{*}{$\mathrm{hp}$} & Negative & 21 & 17 & 14 & 21 & 73 \\
\hline & & $28.8 \%$ & $23.3 \%$ & $19.2 \%$ & $28.8 \%$ & $100 \%$ \\
\hline & Positive & 22 & 9 & 11 & 15 & 57 \\
\hline & & $38.6 \%$ & $15.8 \%$ & $19.3 \%$ & $26.3 \%$ & $100 \%$ \\
\hline \multirow[t]{2}{*}{ Total } & & 43 & 26 & 25 & 36 & 130 \\
\hline & & $33.1 \%$ & $20.0 \%$ & $19.2 \%$ & $27.7 \%$ & $100 \%$ \\
\hline
\end{tabular}

Table 3: The average values of the parameters belong to negativity and positivity of $H$. pylori

\begin{tabular}{ccccc}
\hline age & negative & 73 & $39.4 \pm 16.7$ & 0.8 \\
hb & positive & 57 & $39.0 \pm 14.8$ & 0.8 \\
& negative & 73 & $14.6 \pm 1.4$ & 0.1 \\
hct & positive & 57 & $14.2 \pm 1.6$ & 0.1 \\
& negative & 73 & $42.1 \pm 5.1$ & 0.3 \\
wbc & positive & 57 & $41.2 \pm 4.6$ & 0.3 \\
& negative & 73 & $6.9 \pm 1.6$ & 0.8 \\
sedim & positive & 57 & $6.9 \pm 1.5$ & 0.8 \\
& negative & 73 & $10.6 \pm 11.2$ & 0.2 \\
asc & positive & 57 & $12.8 \pm 11.3$ & 0.2 \\
& negative & 73 & $157.0 \pm 76.1$ & 0.7 \\
crp & positive & 57 & $152.4 \pm 74.3$ & 0.7 \\
& negative & 73 & $4.5 \pm 4.1$ & 0.9 \\
rf & positive & 57 & $3.6 \pm 1.5$ & 0.6 \\
& negative & 73 & $11.3 \pm 2.9$ & 0.3 \\
afp & positive & 57 & $10.9 \pm 2.1$ & 0.3 \\
& negative & 73 & $2.3 \pm 1.7$ & 0.6 \\
cea & positive & 57 & $2.2 \pm 1.2$ & 0.6 \\
& negative & 73 & $1.5 \pm 0.9$ & 0.2 \\
ca19 & positive & 57 & $1.7 \pm 0.7$ & 0.2 \\
& negative & 73 & $10.0 \pm 8.0$ & 0.5 \\
ca153 & positive & 57 & $8.9 \pm 10.4$ & 0.5 \\
& negative & 73 & $15.0 \pm 6.4$ & 0.8 \\
& positive & 57 & $14.7 \pm 5.7$ & 0.8 \\
\hline \multirow{2}{*}{ a } & & &
\end{tabular}

\section{Discussion}

In addition to $H$. pylori infection, nonspecific chronic gastritis and gastric-duodenal ulcers, serious cases of gastric malignancies have been identified. With the eradication of $\mathrm{H}$. pylori, both ulcers healing and recurrence can be prevented. For this reason, in order to determine the ideal treatment period of $H$. pylori infection, gets increasingly important, intensive studies are being carried out all over the world (Aydin et al.,1999).

The natural source of $H$. pylori is not known today. A non-human reservoir could not be shown. Although some natural and animal sources have been reported, this information have not been verified. H. pylori lives in the human pelvis, in the mucus layer in contact with the stomach surface epithelium. Since invasive is not a bacterium, it cannot cross the epithelial layer. Outside of the stomach, only the gastric metaplasia or ectopic gastric mucosa can survive in its areas. There is only mucous affinity that the gastric epithelium secretes. The intrafamilial transmission is especially important during childhood. The main route of transmission should be considered to be fecal-oral as well as oral-oral and gastro-oral routes (Cammarota et al.,1998; Ma et al.,1998).

H. pylori infection is one of the most common chronic infections in the world and effects every human being. In our study, there was no sex-related collagen of $H$. pylori. In some studies, it was reported that men are more prone to $H$. pylori infection (Aslan, 2006; Broutet et al.,2001; Wu et al 2003). In a study conducted by the EUROGAST study group, it was reported that $H$. pylori is not sexdependent, but in studies conducted in France, $H$. pylori infection is more common in males than females (Anonymus,1993; Megraud,1993). On the other hand, studies on the effects of sex on $H$. pylori eradication, the effects of gender haven't found mostly (Türkölmez et al.,2007; Avc1,2007; Megraud,1993; Weill et al.,2002).

The distribution of $H$. pylori positivity according to blood groups has been investigated by many researchers. Some investigators have reported that duedenol ulcer disease is associated with that blood group and gastric ulcer disease is associated with the blood group A (Smith et al.,1994; Mentis et al.,1991; Boren et al.,1993; Robertson et al.,2003. Seyda (2007) reported that $H$. pylori positivity was $72.1,65.1,70$, and $68.4 \%$ in blood groups $\mathrm{A}, \mathrm{B}, \mathrm{AB}$, and $\mathrm{O}(\mathrm{p}=.703)$, and $68.9 \%$ and $76.3 \%$ in $\mathrm{Rh}(+)$ and $\mathrm{Rh}(-)$ blood subgroups, respectively $(\mathrm{p}=.292)$. Investigated, while some researches founded higher in the blood group AB (Türkölmez et al.,2007; Rowland et al.,1997). In another study conducted on 330 patients, it was observed that $H$. pylori infection was not associated with blood groups (Keller et al.,2002). In a study conducted by Mentis et al., $H$. pylori infection was detected in patients who had 
blood group A (Sharara et al.,2006). In addition, another study has investigated whether $H$. pylori is associated with blood groups and $\mathrm{Rh}$ factor. As a result of the study, there was no statistically significant difference in $H$. pylori frequency among the groups in the $\mathrm{C}-14$ urea breath test which is performed by taking into consideration of blood groups and Rh positivity (Milica et al.,2011). In our study, no significant difference was observed between blood groups and $H$. pylori infection with $\mathrm{Rh}$ factor, and no linkage was detected. The distribution rate of $H$. pylori infection among blood groups is close to each other.

A study suggests that the immaturity of innate immunity in children is not fully mature and that this is true for the gastrointestinal system and that the frequency of $H$. pylori infection is high in the childhood group and declining in later ages (Soylu,2006). It was observed that children had a higher rate of $H$. pylori infection than adults and that the infection had decreased in later ages (Türkölmez et al.,2007). Our study also showed similarities to previous studies, showing that children had a higher rate of $H$. pylori infection than adults (data not shown).

The role of epidemiology of $H$. pylori infection in the pathophysiology of gastritis and duodenal ulcers has begun to be better understood. Tests used for diagnosis can separate two groups, non-invasive and invasive. None of these tests are $100 \%$ sensitive and specific for the detection of $H$. pylori alone, and it is suggested that two tests be combined for diagnosis if possible (Usta and Özen,2007). In our study, the presence of $H$. pylori bacteria was detected only by non-invasive C-14 urea breath test.

\section{Conclusion}

In conclusion, $H$. pylori infection is about $43.34 \%$ in Isparta province and causes health problems. No correlation was found with $H$. pylori blood groups and $\mathrm{Rh}$ factor.
Ethics Committee Approval: Ethics committee approval was received for this study from Faculty of Medicine Clinical Research Ethics Committee of Suleyman Demirel University.

Peer-review: Externally peer-reviewed.

Author Contributions: Concept - M.Y., Design M.Y.; Supervision M.Y.; Materials - M.Y.; Data Collection and/or Processing - A.Ş.; Analysis and/or Interpretation - A.Ş.; Literature Review A.Ş.; Writing -A.Ş.; Critical Review - M.Y.

Conflict of Interest: No conflict of interest was declared by the authors.

Financial Disclosure: The authors declared that this study hasn't received no financial support.

\section{References}

Anonymus, 1993. The EUROGAST Study Sroup. Epidemiology of, and risk factors for, $H$. pylori infection among 3194 asymptomatic subjects in 17 populations. The EUROGAST Study Group. Gut 1993; 34:1672-6.

Aslan M. Helicobakter Pilori Pozitif Olan Non Ülser Dispepsili Hastalarda Yüksek Densiteli Lipoproteinin Antioksidan Enzimleri olan Paraoksonoz ve Aritesteraz Aktivitelerinin Araştırılması. Harran Üniversitesi Şanlıurfa 2006;1-10.

Aveı M. Helikobakter Pilori Eradikasyonunda Standart Tedaviye Eklenen N-Asetil Sistein ve Tokoferolün Etkileri. Afyon Kocatepe Ün. Afyon 2007; 1-15.

Aydın A, Günsar F, Yılmaz M, Karasu Z, Özütemiz Ö, İlter T, Tunçyürek M. Ranitidine bismuth citrate based dual and triple therapies in $\mathrm{H}$. pylori eradication The Turkish Journal of Gastroenterology 1999, 10: 202-206.

Biolo G. Toigo G. Ciocchi B. Situlin R. Iscra F. Gullo A. Guarnieri G. Metabolic response to injury and sepsis: changes in protein metabolism. Nutrition 1997 Sep;13(9 Suppl):52S-57S.

Boren T, Falk R, Roth K, Larson G, Normark S. Attachment of $H$. pylori to human gastric epithelium mediated by blood group antigens. Science 1993; 262:1892-5.

Broutet N, Sarasqueta AM, Sakarovitch C, Cantet F, Lethuaire D, Megraud F. H. pylori infection in patients consulting gastroenterologists in France: prevalence is linked to gender and region of residence. Eur J Gastroenterol Hepatol 2001; 13:677-84. 
Cammarota G. Tursi A. Papa A. Veneto G. Bernadi S. Boari A. Colizzi V. Fedeli G. Gasbarrini, 1998. G. Role of dental plaque in the transmission of Helicobakter pylori infection. J Clin Gastroenterol 1998; 22:174-177.

Cavallini A. Notarnicola M. Berloco P. Use of macroporous polypropylene filter to allow identification of bacteria by PCR in human fecal samples. J Microbiol Methods 2000; 39:265-70.

Drumm B. Rhoads JM. Stringer DA. Peptic ulcer disease in children: etiology. clinical findings. and clinical course. Pediatrics 1988; 82: 410414.

Dunn BE. Cohen H. Blaser MJ. Helicobakter pylori. Cinical Microbiology Reviews 1997; 10:720741.

Gramley WA. Asghar A. Frierson HF. Powell SM. Detection of $H$. pylori DNA in fecal samples from infected individuals. J Clin Microbiol 1999; 37: 2236-40

Greg 1. Perkıns. M.D. Evan D. Slater. M.D. Georganne K. Sanders. M.D...and John G. Prichard. M.D. Serum Tumor Markers. American Famıly Physician 2003; 1075-81.

Gürakan F. Koçak N. Yüce A. H. pylori serology in childhood. Turk J Pediatr 1996; 38: 329-334.

Hino B. Eliakim R. Levine A. et al. Comparison of invasive and non-invasive tests diagnosis and monitoring of $H$. pylori infection in children. $\mathrm{J}$ Pediatr Gastroenterol Nutr 2004; 39: 519-523.

Keller R, Dinkel KC, Christl SU, Fischbach W. Interrelation between $\mathrm{ABH}$ blood group $\mathrm{O}$, Lewis (B) blood group antigen, $H$. pylori infection, and occurrence of peptic ulcer. $\mathrm{Z}$ Gastroenetrol 2002; 40:273-6.

Laine L. Fennerty MB. Osato M. Sugg J. Suchower L. Probst P. Levine JG. Esomeprazole-based $H$. pylori eradication therapy and the effect ofantibiotic resistance: results of three US multicenter. double-blind trials. Am JGastroenterol2000; 95.3393-8.

Logan RP. Polson RJ. Misiewicz JJ. Simplified single sample 13 carbon urea breath test for $H$. pylori: comparison with histology. culture. and ELISA serology. Gut 1991; 32: 1461-1464.

Ma JL. Yol WC. Gail MH. Zhang L. Blot WJ. Chang YS. JiangJ. Liu WD. Hu YR. Brown LM. $\mathrm{Xu}$ GW. Fraumeni JF. Helicobakter Pylori infektion and mode of transmission in a population at high risk of stomach cancer. Int $\mathrm{J}$. Epidemiol 1998; 27: 570-573.
Manes G. Balzano A. Iaquinto G. Accuracy of stool antigen test in posteradication assessment of $H$. pylori infection. Dig Dis Sci 2001; 46: 2440244410.

Megraud F. Epidemiology of H. pylori infection. Gastroenterol Clin North Am 1993; 22:73-88.

Milica Lj. Stojkovi\}, Darija R. Durutovi\}, Milorad N. Petrovi\}, Mirjana V. Stojkovi\}, Neboj \{a S. Petrovi\}, AndrijaA. Anti\}, Vladimir B. Obradovi\}, 2011. H. pylori infection in various groups ofpatients studied, estimated by $14 \mathrm{C}$ urea breath test. Acta Chirurgica Iugoslavica 58(1):95-8

Mentis A, Blackwell CC, Weir DM, Spiliadis C, Dailianas A, Skandalis N. ABO blood groups, secretor status, and detection of $H$. pylori among patients with gastric or duodenal ulcer. Epidemiol Infect 1991; 106:221-9.

Ozcay F. Koçak N. Saltık Temizel IN. H. pylori infection in Turkish children: comparison of diagnostic tests. evaluation of eradication rate. and changes in symptoms after eradication. Helicobacter 2004; 9: 242-248.

Robertson MS, Cade JF, Savoia HF, Clancy RL. $H$. pylori infection in the Australian community: current prevalence and lack of association with ABO blood groups. Int Med J 2003; 33:163-7.

Rowland M. Lambert I. Gormally S. Carbon 13labeled urea breath test for the diagnosis of $H$. pylori infection in children. J Pediatr 1997; 131: 815-820.

Schabereiter-Gurtner C. Hirschl AM. Dragosics B. Novel real-time PCR assay for detection of $H$. pylori infection and simultaneous clarithromycin susceptibility testing of stool and biopsy specimens. J Clin Microbiol 2004; 42: 45124518

Seyda T, Derya C, Füsun A, Meliha K. The relationship of Helicobacter pylori positivity with age, sex, and $\mathrm{ABO} /$ Rhesus blood groups in patients with gastrointestinal complaints in Turkey. Helicobacter. 2007 Jun;12(3):244-50.

Sharara AI, Abdul-Baki H, Elhajj I, Kreidieh N, Kfoury Baz EM. Association of gastroduodenal disease phenotype with $\mathrm{ABO}$ blood group and $H$. pylori virulence-specific serotypes. Dig Liver Dis 2006; 38:829-33.

Smith AW, Aathithan S, Power EG, Abdulla Y. Blood group antigens and $H$. pylori infections. Lancet 1994; 343:543. 
Stojković MLj., Durutović DR., Petrović MN., Stojković MV., Petrović NS., Antić AA., Obradović VB. H. pylori infection in various groups ofpatients studied, estimated by 14C urea breath test. Acta Chirurgica Iugoslavica 2011; 58(1):95-8.

Soylu Ö. Çocuklarda Helikobakter Pilori Enfeksiyonunda Mide dokusunda $\alpha$-defensin ekspresyonu. Dokuz Eylül Üniversitesi İzmir 2006; 45.

Türkölmez Ş. Çayır D. Aydoğan F. Korkmaz M. The Relationship of Helicobakter Pylori Positivity with Age. Sex and ABO/Rhesus Blood Groups in Patients with Gastrointestinal Complaints in Turkey. Helicobakter 2007; 12: 244-250.

Usta Y. Özen H. Helicobakter pylori enfeksiyonu. Cocuk Sağlı̆̆ı ve Hastalıkları Dergisi Ankara 2007.

Volanakis JE. Human C-reactive protein: expression. structure. and function. Mol Immunol 2001 Aug;38(2- 3):189-97.

Weill FX, Margeridon S, Broutet N, Le Hello S, Neyret C, Megraud F. Seroepidemiology of $H$. pylori infection in Guadeloupe. Trans $\mathrm{R}$ Soc Trop Med Hyg 2002; 96:517-9.

Wu T-C, Chen L-K, Hwang S-J. Seroprevalence of H. pylori in school- aged Chinese in Taipei City and relationship between $\mathrm{ABO}$ blood groups. World J Gastroenterol 2003; 9:1752-5.

Yilmaz YA. Helicobakter pylori: mikrobiyolojik tanı yöntemleri. Hacettepe4 T1p Dergisi Ankara 2004; 183. 